Biogeosciences, 10, 2821-2831, 2013

www.biogeosciences.net/10/2821/2013/

doi:10.5194/bg-10-2821-2013

(c) Author(s) 2013. CC Attribution 3.0 License.

\title{
Interconnectivity vs. isolation of prokaryotic communities in European deep-sea mud volcanoes
}

\author{
M. G. Pachiadaki and K. A. Kormas \\ Department of Ichthyology \& Aquatic Environment, School of Agricultural Sciences, University of Thessaly, \\ 38446 Volos, Greece
}

Correspondence to: K. A. Kormas (kkormas@uth.gr)

Received: 11 November 2012 - Published in Biogeosciences Discuss.: 7 December 2012

Revised: 29 March 2013 - Accepted: 8 April 2013 - Published: 2 May 2013

\begin{abstract}
During the past two decades, European cold seep ecosystems have attracted the scientific interest and to date there are several studies which have investigated the community structure and biodiversity of individual sites. In order to gain a better insight into the biology, biodiversity, and biogeography of seep-associated microbial communities along Europe's continental margins, a comparative approach was applied in the present work. By exploiting the publicly available data on 16S rRNA gene sequences retrieved from sediments of the Håkon Mosby mud volcano, Gulf of Cádiz and the eastern Mediterranean mud volcanoes/pockmarks (Anaximander area and Nile Fan), we investigated the prokaryotic biological components connecting these geographically isolated systems. The construction of interaction networks for both archaeal and bacterial shared operational taxonomic units (OTUs) among the different sites, revealed the presence of persistent OTUs, which can be considered as "keyplayers". One archaeal OTU (HQ588641) belonging to the ANME-3 group and one $\delta$-Proteobacteria (HQ588562) were found in all five investigated areas. Other Archaea OTUs shared between four sites or less, belonged to the ANME-2c, -2a, MBG-D, -B and Thaumarchaeota. All other shared Bacteria belonged to the $\delta$ - and $\gamma$-Proteobacteria, with the exception of one JS1 affiliate OTU. The distribution of the majority of the shared OTUs seems to be restricted in cold seeps, mud volcanoes and other marine methane-rich environments. Although the investigated sites were connected through a small number of OTUs, these microorganisms hold central ecophysiological roles in these sediments, namely methane- and sulfur-mediated mineralization.
\end{abstract}

\section{Introduction}

Cold seeps support an enormous biomass of free-living and symbiotic microbial life that is nourished by the oxidation of methane, higher hydrocarbons and sulfide. In fact, methanefuelled microbial communities in anoxic sediments above gas hydrates and gas vents have the highest biomass known to occur in marine ecosystems, with up to $10^{12}$ cells $\mathrm{cm}^{-3}$ (Boetius et al., 2000). Because of their distinct biogeochemistry dominated by fluid flow and hydrocarbon transport, methanotrophs, hydrocarbon degraders, sulfate-reducing and sulfide-oxidizing Bacteria are the key functional groups at cold-seep ecosystems. During the European Commission's Framework Six Programme HERMES and Framework Seven Programme HERMIONE, many marine sites have been investigated along the European margin which are characterized by the presence of various seep-related structures with different intensity of activity and biological diversity. Unraveling the associated biodiversity and understanding the driving forces and function of the seep-associated ecosystems by means of an integrated approach comprised one of the research topics of the projects (Vanreusel et al., 2009). Through the research activities of the above-mentioned programs, three main areas harbouring prominent seep ecosystems have been recognised: (1) the Nordic margin with the Håkon Mosby mud volcano (HMMV) and many pockmarks, (2) the Gulf of Cádiz (GoC), and (3) the eastern Mediterranean with ample mud volcanoes and brine pool structures.

Along the Nordic margin, the highly active HMMV is situated at the Norwegian-Barents-Spitzbergen continental margin at $1250 \mathrm{~m}$ water depth and was first located in 1989 during a side scan survey. An expedition in 1995 revealed 
very steep temperature gradients in the sediments, recovered methane hydrate from $2 \mathrm{~m}$ below sea floor (b.s.f.) while siboglinid tubeworms were also found, suggesting active chemosynthesis (Vogt et al., 1997). The concentric structure of the HMMV can be divided in several sub-habitats characterized by significantly different biogeochemical sediment conditions (Niemann et al., 2006a; De Beer et al., 2006).

Mud volcanism in the $\mathrm{GoC}$ is characterized by a wide diversity of processes and environmental settings, such as different types of fluid migration pathways, tectonic activity and/or salt diapirism, migration velocity, fluid composition and alteration processes, depth, sea bottom temperature (from $4{ }^{\circ} \mathrm{C}$ to $13{ }^{\circ} \mathrm{C}$ if under the influence of the Mediterranean outflow water), and the presence of gas hydrates. The migrating fluid and mud reaching the surface is of very deep origin (Hensen et al., 2007). In the Gulf of Cádiz, overall activity for the anaerobic oxidation of methane (AOM) is typical for low to moderately active seeps (Maignien et al., 2013; Niemann et al., 2006b). Discrete AOM hotspots, exhibiting activity one order higher than the typical sites, have been observed. There, the development of white bacterial mats is sustained. In contrast, salt diapir-driven mud volcanoes characterized by hypersaline pore water show low microbial activity, although methane and sulfate are present in large amounts. Interestingly, these environmental setting variations and AOM activity are reflected by diverse microbial community compositions.

In the eastern Mediterranean Sea, mud volcanoes (MV) and cold seep areas were discovered during the late 1970s (e.g Cita et al., 1981) while ongoing research has revealed several such formations on the accretionary prism of the Hellenic Arc (Mediterranean Ridge) and within the Anaximander Mountains (Woodside et al., 1998; Lykousis et al., 2004) as well as the seafloor of the Nile deep sea fan (NDSF) (Loncke and Mascle, 2004). The Anaximander area, located at depths between $1700 \mathrm{~m}$ to $2000 \mathrm{~m}$, is characterized by strong compressional tectonic processes superimposed by faulting. It harbours large conical MV of several $\mathrm{km}$ across but only a few hundred meters high. Fresh mud flows, brines, clasts and carbonate crusts may be observed on their surface, depending on the current activity of the volcano (Zitter et al., 2005). Two of the biggest and more active volcanoes of the area are Amsterdam MV (AMSMV) and Kazan MV (KZNMV). The Nile deep turbidic system displays many fluid-releasing structures on the seafloor including mud volcanoes, mud pies and pockmarks (Loncke and Mascle, 2004). The mud volcanoes of NDSF (Amon and Isis of the Eastern, North Alex of the Central and Chefren and Mykerinos of the Western NDSF) are circular features (1-3 km in diameter) in water depths of 500-3000 $\mathrm{m}$ with elevations of up to $100 \mathrm{~m}$ above the seabed. They are located above well-developed feeder channels, clearly seen on the seismic data (Loncke and Mascle, 2004; Dupré et al., 2007). The presence of brine mud basins within the volcano craters has also been reported (Omoregie et al., 2008).

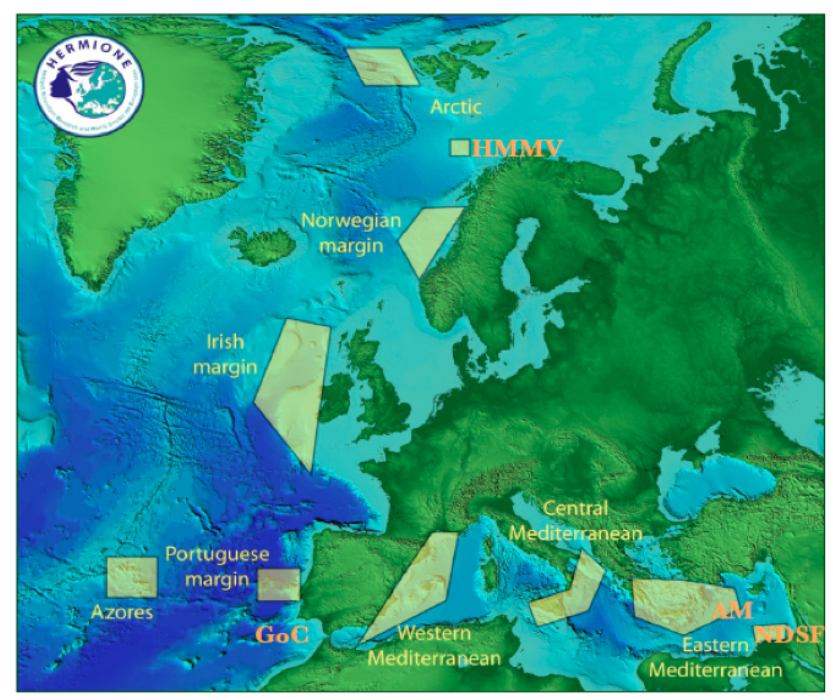

Fig. 1. Map of the European marginal seas. HMMV: Håkon Mosby mud volcano, GoC: Gulf of Cádiz, AM: Anaximander Mountains, NDSF: Nile deep-sea fan.

Following one of the key objectives of HERMIONE, i.e. the distribution and interconnection of deep-sea ecosystems, in this paper we exploit the available data on prokaryotic occurrence in the sediments of the HMMV, Gulf of Cadiz and eastern Mediterranean MV/pockmarks (Fig. 1) and explore whether these systems are characterized by high (interconnectivity) or low (isolation) degree of shared bacterial and archaeal species. Such comparisons among distant ecosystems but with similar dominant microbial processes can provide meaningful information about the spatial and temporal scales of variability. Towards this, we investigated the occurrence of published 16S rRNA gene sequences in these habitats. In particular we aimed at elucidating the shared bacterial and archaeal phylotypes between the three sites, as it is hypothesized that such species are best candidates for having a predominant role in ecosystem functioning (Konopka, 2009).

\section{Materials and methods}

In this study, the analyses were performed on 16 data sets consisting of 16S rRNA gene sequences (Table 1) originating from eight individual projects. The data sets were retrieved from GenBank (http://www.ncbi.nlm.nih.gov/) from the 15 June 2012 release. Prokaryotic SSU rRNA sequences were identified as records that had any of the terms: "16S", "16S SSU", or "small subunit" and "prokaryotic"/"archaeal"/"bacterial" "ribosomal RNA", together with terms used to select for location: "Håkon Mosby", "Gulf of Cadiz", "Nile Fan", "Amsterdam mud volcano", "Kazan mud volcano", "eastern Mediterranean mud volcanoes" (Fig. 1), Data sets that contained only short sequences (less than $700 \mathrm{bp}$ ) were excluded from the analysis. We excluded 
Table 1. Data sets of $16 \mathrm{~S}$ rRNA gene sequences used in this study. For sites codes see text.

\begin{tabular}{llllll}
\hline & & & \# of unique & \\
Code & Site & Site & Domain & OTUs & Reference \\
\hline AMSMV Pac Bac & Amsterdan MV & $35^{\circ} 20.03^{\prime} \mathrm{N}, 30^{\circ} 16.30^{\prime} \mathrm{E}$ & Bacteria & 213 & Pachiadaki et al. (2011) \\
AMSMV Pac Arc & Amsterdan MV & $35^{\circ} 20.03^{\prime} \mathrm{N}, 30^{\circ} 16.30^{\prime} \mathrm{E}$ & Archaea & 25 & Pachiadaki et al. (2011) \\
AMSMV Heij Bac & Amsterdan MV & $35^{\circ} 20.00^{\prime} \mathrm{N}, 30^{\circ} 16.00^{\prime} \mathrm{E}$ & Bacteria & 92 & Heijs et al. (2008) \\
AMSMV Heij Arc & Amsterdan MV & $35^{\circ} 20.00^{\prime} \mathrm{N}, 30^{\circ} 16.00^{\prime} \mathrm{E}$ & Archaea & 29 & Heijs et al. (2008) \\
KZNMV Pac Bac & Kazan MV & $35^{\circ} 25.92^{\prime} \mathrm{N}, 30^{\circ} 33.70^{\prime} \mathrm{E}$ & Bacteria & 176 & Kormas et al. (2008); Pachiadaki et al. (2010) \\
KZNMV Pac Arc & Kazan MV & $35^{\circ} 25.92^{\prime} \mathrm{N}, 30^{\circ} 33.70^{\prime} \mathrm{E}$ & Archaea & 19 & Kormas et al. (2008); Pachiadaki et al. (2010) \\
KZNMV Heij Bac & Kazan MV & $35^{\circ} 25.90^{\prime} \mathrm{N}, 30^{\circ} 33.70^{\prime} \mathrm{E}$ & Bacteria & 117 & Heijs et al. (2007) \\
KZNMV Heij Arc & Kazan MV & $35^{\circ} 25.90^{\prime} \mathrm{N}, 30^{\circ} 33.70^{\prime} \mathrm{E}$ & Archaea & 45 & Heijs et al. (2007) \\
HMMV Los Bac & Håkon Mosby MV & $72^{\circ} 00.25^{\prime} \mathrm{N}, 14^{\circ} 43.50^{\prime} \mathrm{E}$ & Bacteria & 60 & Lösekann et al. (2007) \\
HMMV Los Arc & Håkon Mosby MV & $72^{\circ} 00.25^{\prime} \mathrm{N}, 14^{\circ} 43.50^{\prime} \mathrm{E}$ & Archaea & 13 & Lösekann et al. (2007) \\
NDSF Omo Bac & Nile deep sea fan & $32^{\circ} 06.74^{\prime} \mathrm{N}, 28^{\circ} 10.35^{\prime} \mathrm{E}$ & Bacteria & 202 & Omoregie et al. (2008) \\
NDSF Omo Arc & Nile deep sea fan & $32^{\circ} 06.74^{\prime} \mathrm{N}, 28^{\circ} 10.35^{\prime} \mathrm{E}$ & Archaea & 37 & Omoregie et al. (2008) \\
GoC Mai Bac & Gulf of Cadiz & & Bacteria & 82 & Unpublished data* \\
GoC Mai Arc & Gulf of Cadiz & & Archaea & 24 & Unpublished data* \\
GoC Nie Bac & Gulf of Cádiz & $35^{\circ} 39.72^{\prime} \mathrm{N}, 07^{\circ} 19.98^{\prime} \mathrm{E}$ & Bacteria & 11 & Niemann et al. (2006a) \\
GoC Nie Arc & Gulf of Cádiz & $35^{\circ} 39.72^{\prime} \mathrm{N}, 07^{\circ} 19.98^{\prime} \mathrm{E}$ & Archaea & 9 & Niemann et al. (2006a) \\
\hline
\end{tabular}

* Maignien, L. and Boon, N. (submitted to GenBank on 26-04-2010). Activity and distribution of anaerobic methananotrophs in mud volcanoes from the Gulf of Cadiz, unpublished data. Archaea accession numbers: FN820355-FN820437; Bacteria accession numbers: FN820294-FN820354.

studies containing short sequences $(<700 \mathrm{bp}$, i.e. less than half of the 16S rRNA gene's length), e.g. DGGE sequences, because in such short sequences even low nucleotide (nt) variation can have major impact on the \% of sequence similarity. All the studies analysed here targeted the nearly full length of the 16S rRNA gene (1200-1400 nt). In a couple of cases, researchers deposited along with the full length sequences a few shorter ones (700-950 nt). These sequences are included in our analysis, as they fulfill the $>700 \mathrm{bp}$ criterion. In order to test if the length of these sequences affects the $\%$ of sequence similarity, which would change the number of the shared OTUs, we performed the comparisons (i) without manipulations, i.e. sequences were used as deposited in GenBank; (ii) using the shorter sequence to trim all sequences to this length in all data sets. Using the $98 \%$ cut off criterion, the number of the common OTUs between the databases remained the same (data not shown). For each data set, clusters of Operational Taxonomic Units (OTUs) or phylotypes were generated based on $\geq 98 \%$ rRNA gene sequence similarity levels by multiple sequence alignment using ClustalW2 (Larkin et al., 2007). The generated data sets with the unique OTUs were compared to one another and the number of common OTUs between each analysed pair of data sets was noted. Similarity matrices, one for Archaea and one for Bacteria, based on the number of common OTUs retrieved, were created. Network visualisations were performed by using the Cytoscape software, version 2.8.2 (Smoot et al., 2011).

The phylogenetic affiliation of the common OTUs was identified by their placement into phylogenetic trees. The trees were constructed from aligned sequences using the SILVA alignment utility (Pruesse et al., 2007) (http://www. arb-silva.de/aligner/), release 108 of the SSU database by the neighbour-joining method using the Kimura 2-parameter. Bootstrap analyses for 1000 replicates were performed to assign confidence levels to the tree topology using the MEGA5 software (Tamura et al., 2011). The dispersal (or presence in a global scale) of each one of the common OTUs was investigated using the Basic Local Alignment Search Tool (http://blast.ncbi.nlm.nih.gov/).

\section{Results and discussion}

Disentangling the different temporal and spatial scales of deep-sea microbial communities can distinguish diversity deserts from hotspots and relate these microorganisms and/or their metabolic traits to the prevailing environmental factors. In addition, meaningful working hypotheses can be securely set on the interconnectivity or isolation of such communities (Gonzalez et al., 2012). Regarding deep-sea MVs, the benefit from such an approach lies mostly in the spatial scale, since their unpredictable eruption frequencies and/or changes in fluids flow, along with the sampling limitations due to the depth they occur, render the investigation of their microbial communities temporal changes unfeasible for the time being. Thus, in this paper we attempt to recognise shared bacterial and archaeal phylotypes among three major methane-related sites of the European margin (Fig. 2). Such common phylotypes can be considered as fundamental species for these habitats (Konopka, 2009; Magurran and McGill, 2010), based on their global distribution and inferred metabolic traits. Our study did not aim to relate OTU occurrence with prevailing chemical conditions because not all sites have been studied for this in the same detail/parameters. We consider methane and other hydrocarbons flow as their most characteristic feature. 

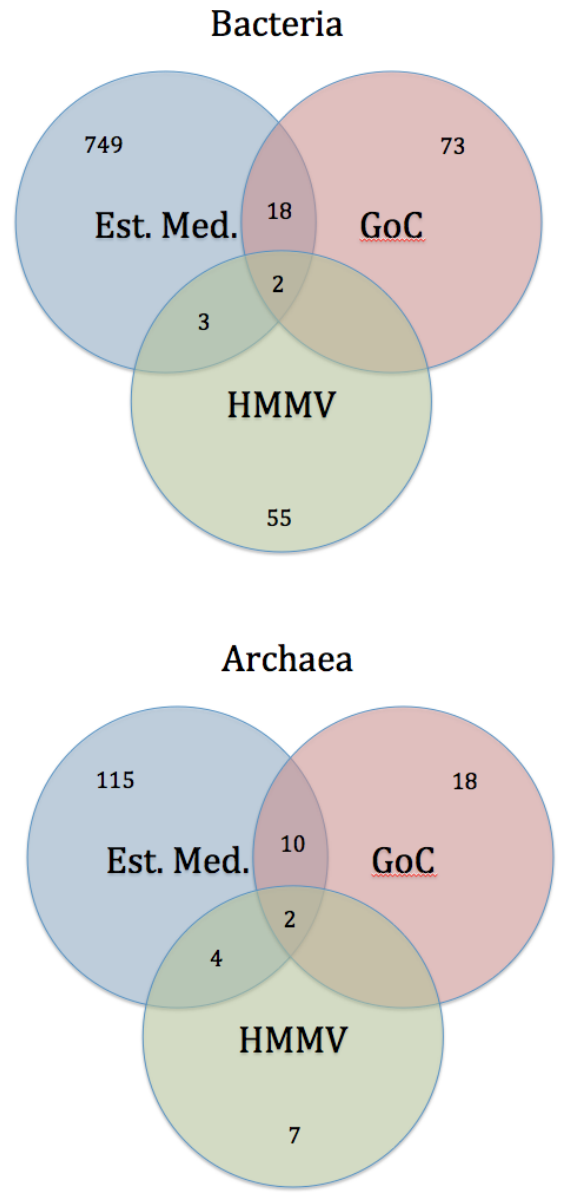

Fig. 2. Venn diagram of the shared phylotypes between the eastern Mediterranean (Est. Med.), the Gulf of Cádiz (GoC) and the Håkon Mosby (HMMV) mud volcanoes.

As the number of data sets we investigated were more than three, we used network visualization in order to depict the most connected mud volcanoes based of the shared OTUs between these data sets (Fig. 3) and show at the same time which OTUs connect the investigated sites in the different studies (Fig. 4). The percentage of shared archaeal OTUs between the three major sites we studied was $12.2 \%, 40.0 \%$ and $46.1 \%$ for the eastern Mediterranean, the Gulf of Cadiz and the HMMV, respectively, while the corresponding values for Bacteria were $3.0 \%, 21.5 \%$ and $8.3 \%$ (Fig. 2). In a recent synthesis study, by comparing 9.6 million bacterial V6-rRNA amplicons from 509 samples spanning from the global ocean's surface to the deepsea floor, it was considered that the $10 \%$ of shared bacterial types between the pelagic and benthic communities implies greatly different communities (Zinger et al., 2011). Despite the much smaller data sets we used and the technical discrepancies between the individual studies, we observed higher percentages of shared OTUs, especially for the Archaea, suggesting that these habitats are somewhat interconnected via
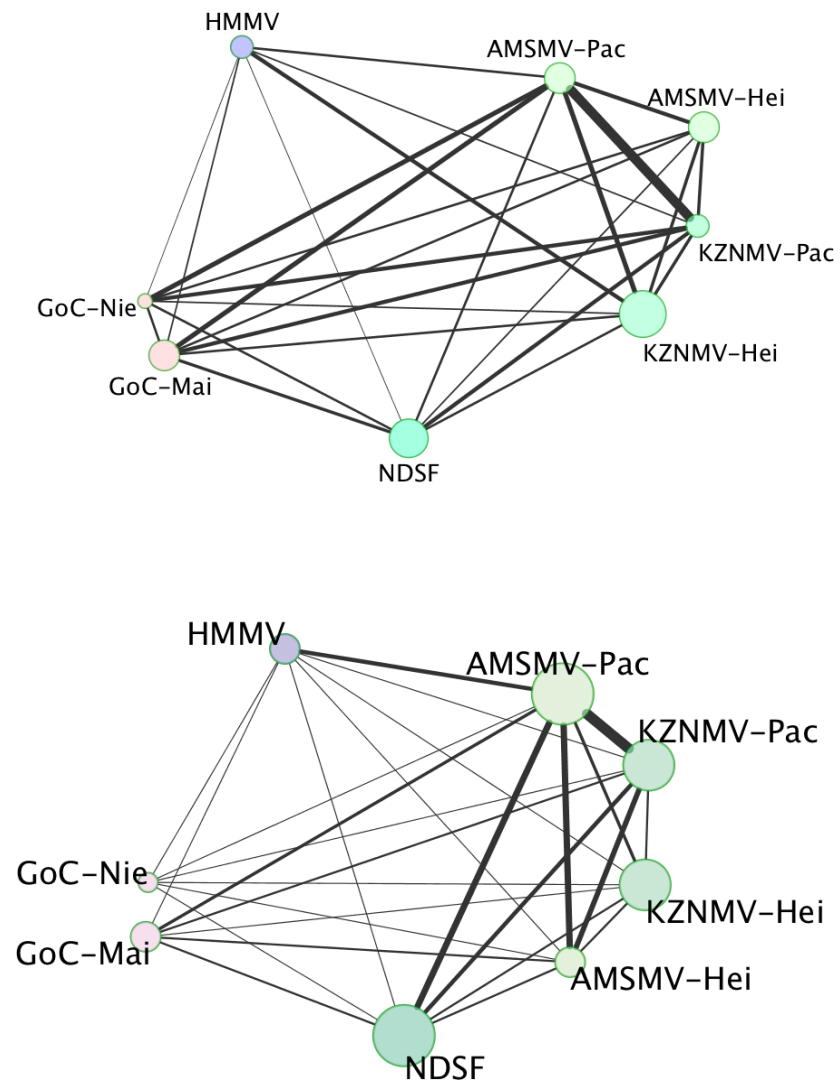

Fig. 3. Degree of connectivity between the 16 data sets analysed based on the archaeal (top) and bacterial (bottom) shared OTUs. The thickness of the links is relative to the number of shared OTUs (1-12 and 1-37 for Archaea and Bacteria, respectively) and the size of the each node is relative to the number of unique OTUs found in each site (9-45 and 11-213 for Archaea and Bacteria, respectively).

these phylotypes. Pairwise comparisons of the specific studies showed even higher percentages between certain studies (Table 2, Fig. 3). Whether these common phylotypes could be key-stone species for these habitats remains to be investigated with ecophysiological approaches, but it seems that the occurrence of these microorganisms is rather restricted to very similar habitats, i.e. methane-dominated sediments (see below). The endemic character of these microorganisms consists a clear demonstration of biogeographic pattern of methane-dominated deep-sea sediments, as it happens in other highly specific or extreme environments like hydrothermal vents (Hanson et al., 2012). The differences in the percentage of shared phylotypes - for both Bacteria and Archaea - could be partially attributed to the different depth of analysis and/or different sampling effort. For example, the data sets of Pachiadaki et al. (2010, 2011), had the highest spatial resolution (i.e. vertical sediment sampling) and it was between these two sites that the highest number (12 and 37 for Archaea and Bacteria, respectively) of common OTUs were found. Fine-scaled spatial sampling and higher number 

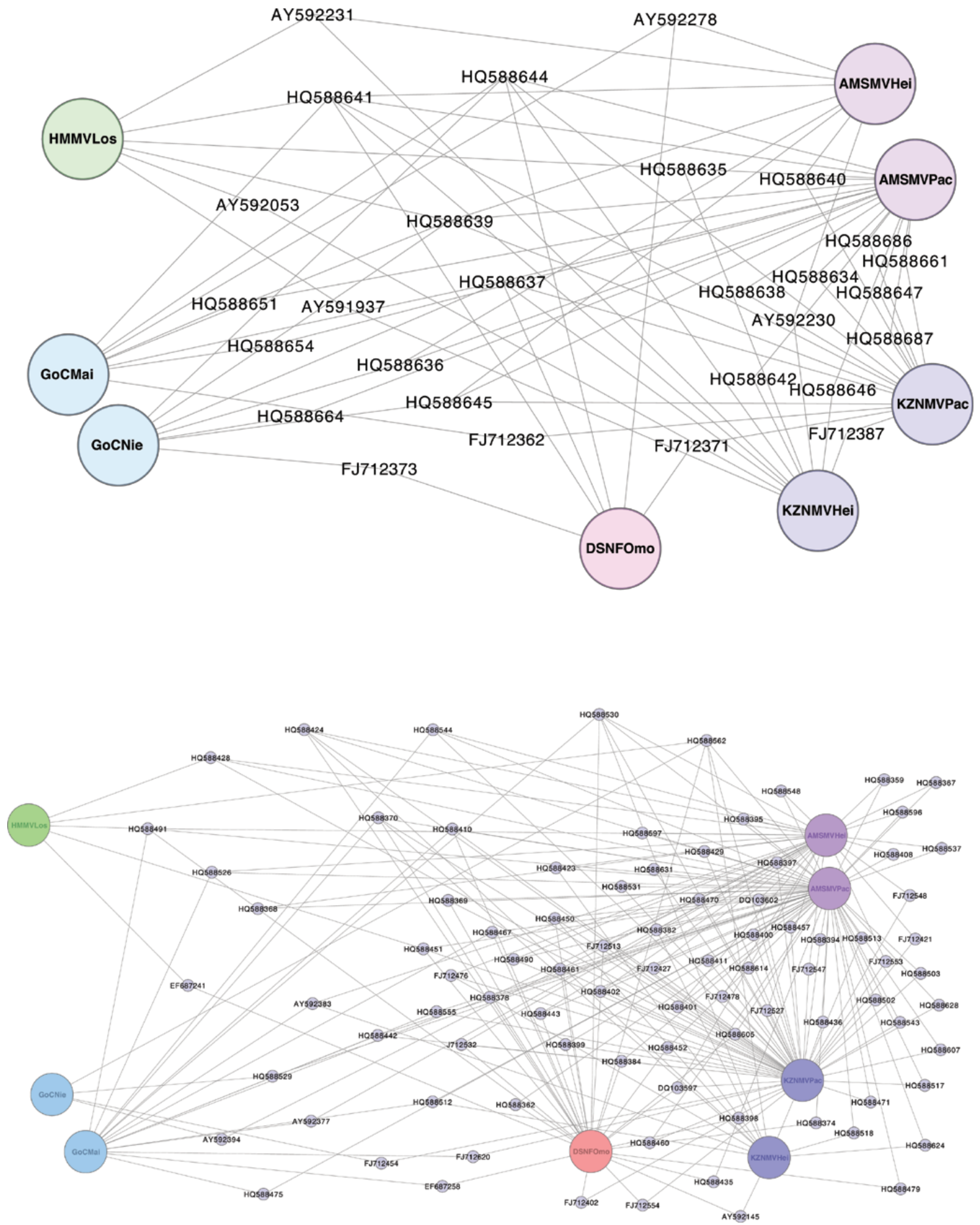

Fig. 4. Microbial network of the examined sites (represented by the external nodes). The shared archaeal (top) and bacterial (bottom figure) OTUs are represented as internal nodes with their GenBank accession numbers. 
of sequenced clones will more likely increase the number of resulting OTUs per sample. However, an increase in retrieved phylotypes does not necessarily imply a proportional increased of shared OTUs as deeper sequencing reveals more rare phylotypes.

\subsection{Archaea}

In all studies considered here, the number of retrieved archaeal OTUs was lower than the bacterial. The lower archaeal vs. bacterial species' richness seems to apply to hydrate-bearing sediments, cold seeps as well as MVs and is possibly a general trend in methane-related environments (Pachiadaki et al., 2010, and references therein).

The OTU comparison among the different data sets (Tables 2 and 3) revealed that the number of shared OTUs is high. Considering the low number of retrieved total archaeal OTUs (less than 30 in all but one data sets), the shared OTUs have a substantial relative abundance. The highest number of shared OTUs was found between AMSMV Pac and KZNMV Pac databases, having 12 OTUs $(48.0 \%$ and $63.1 \%$ of their total archaeal OTUs, respectively) in common.

To further examine the key players in this microbial network (Fig. 4), the identity and the potential role of the internal nodes with the highest number of edges, namely the more common OTUs, were examined. The most common one representative sequence HQ588641 - retrieved in seven data sets and in all examined sites, was affiliated with the anaerobic methane oxidizing euryarchaeotal group, ANME-3. The ANME-3 group has been found to dominate in sediments of the Håkon Mosby MV and believed to perform AOM either without obligatory physical association with a sulfate reducing partner or with alternative partners (Lösekann et al., 2007). This group is related only with methane rich environments, but it seems that within these environments is more widely spread than initially assumed. This specific OTU, HQ588641, was reported from a variety of locations, such as methane seep of Yung-An ridge (GU553624) and subseafloor gas-hydrate sediments at the Kaoping Canyon (JQ817531) in SW Taiwan, deep-sea methane seep sediment from Nankai Trough, Japan (AB461393); methane seeps of Hikurangi Margin, New Zealand (JF268331); Mississippi canyon, Gulf of Mexico (GU190976); Hydrate Ridge Cascadia Margin (AM229243) and Eel River basin (AF354136). Abundance data that could be retrieved from some of the studies indicate that this OTU dominated specific habitats in those locations, such as the sediment below Beggiatoa mats (Lösekann et al., 2007). The vertical distribution of the archaeal communities in the Amsterdam and Kazan MVs (Pachiadaki et al., 2010, 2011) revealed that this OTU is present in all sediment layers reaching up to a relative abundance of $\sim 70 \%$ at $30 \mathrm{~cm}$ b.s.f. in Amsterdam MV.

Three OTUs, HQ588637, HQ588644 and HQ588639 were present in six of the data sets and in four (out of the total five) locations. They all were identified as anaerobic methane oxidizers belonging to the groups ANME-2c, ANME-2a and ANME-1, respectively. These OTUs have a worldwide distribution, but their presence, as before, is restricted in habitats where AOM is a key process: from the cold sediments of Skan Bay, Alaska (DQ640143; DQ5229339) and the methane seeps, northern North Sea (FM179890; FM179862) to the gas hydrate sediments of the Hydrate Ridge (AM229230; AM229254; AM713449), the hydrocarbon seeps of the Gulf of Mexico (GU190995; GU190981; DQ521780) and the hydrothermal sediments in the Guaymas Basin (F419650; FP565147). The OTUs of ANME-1 and ANME-2 groups were found to co-occur in all examined data sets, which is a rather common finding in AOM related studies (Dhillon et al., 2005; Knittel et al., 2005; Mills et al., 2005; Orphan et al., 2002) since it seems that, although phylogenetically distant, these groups perform AOM in a wide range of environmental settings. Our data further revealed that actually there is a co-occurrence of all three anaerobic methane oxidizing groups, ANME-1; ANME-2 (both 2a and $2 \mathrm{c}$ subgroups) and ANME-3. The shared ANME-1 OTU (HQ5886439) was also retrieved in AOM performing microbial mat from the Back Sea (FP565147) (Meyerdierks et al., 2010), which is a habitat dominated by the ANME1 Archaea. All three phylotypes were found in high abundances in eastern Mediterranean MVs. The ANME-2c OTU (HQ588637) dominated the surface clone library of Kazan MV ( $\sim 87 \%$ of all archaeal clones) and the $25 \mathrm{~cm}$ b.s.f. layer of Amsterdam MV ( 39\%), the ANME-2a (HQ588644), appeared at Amsterdam MV with a relative abundance reaching $\sim 55 \%$ in the $10 \mathrm{~cm}$ b.s.f. clone library and at Kazan MV $\sim 40 \%$ in the $30 \mathrm{~cm}$ b.s.f. clone library. The ANME- 1 (HQ588639) was also abundant with $\sim 31 \%$ and $22 \%$ for $5 \mathrm{~cm}$ b.s.f. Amsterdam MV and $10 \mathrm{~cm}$ b.s.f. Kazan MV, respectively.

The next common OTU (HQ588645) shared among four of the data sets was affiliated to MBG-D, Marine Benthic Group-D, (synonymous with marine group III, MG-III, a lineage within the Thermoplasmatales). For this group it is difficult to suggest potential ecophysiological roles, other than its association with the deep subsurface (Teske and Sørensen, 2008) and especially with methane rich environments (Biddle et al., 2011). This OTU seems to be present in several AOM hot-spots. The OTUs HQ588636, HQ588640 and FN820369 (each common among three of the data sets) also belong to the MBG-D. All of them are exclusively found in methane rich habitats indicating that this group together with the ANME is probably playing an important role in the process of AOM.

One crenarchaeotal OTU, HQ588636, belonging to MBGB, Marine Benthic Group-B (synonymous with Deep Sea Archaeal Group) is present in three of the data sets. This group of Archaea is thought to represent one of the dominant archaeal lineages in clone libraries of archaeal 16S rRNA and occurs in a wide range of sampling sites and sediment types (Teske and Sørensen, 2008) but perhaps that is not the case 
Table 2. Most widely occurring phylotypes of Archaea and Bacteria in European marine mud volcanoes. For sites codes see text.

\begin{tabular}{|c|c|c|c|c|c|c|}
\hline & Affiliation & Amsterdam $^{\mathrm{a}}$ & Kazan $^{\text {b }}$ & Håkon Mosby & $\begin{array}{c}\text { Nile deep-sea } \\
\text { Fan }\end{array}$ & $\begin{array}{l}\text { Gulf of } \\
\text { Cádiz }\end{array}$ \\
\hline \multicolumn{7}{|l|}{ Archaea } \\
\hline HQ588641 & ANME-3 & + & + & + & + & + \\
\hline HQ588637 & ANME-2c & + & + & - & + & + \\
\hline HQ588644 & ANME-2a & + & + & - & + & + \\
\hline HQ588639 & ANME-1 & + & + & + & - & + \\
\hline HQ588645 & MBG-D & + & + & - & - & + \\
\hline AJ704644 & Thaumarchaeota & + & + & + & - & - \\
\hline HQ588635 & Thaumarchaeota & + & + & + & - & - \\
\hline FJ712373 & MBG-D & - & + & - & + & + \\
\hline FN820369 & MBG-D & + & - & - & + & + \\
\hline HQ588636 & MBG-B & + & - & - & - & + \\
\hline \multicolumn{7}{|l|}{ Bacteria } \\
\hline HQ588562 & $\delta$-Proteobacteria & + & + & + & + & + \\
\hline HQ588530 & $\delta$-Proteobacteria & + & + & - & + & + \\
\hline HQ588370 & $\delta$-Proteobacteria & + & + & - & + & + \\
\hline HQ588491 & $\delta$-Proteobacteria & + & - & + & + & + \\
\hline HQ588410 & $\delta$-Proteobacteria & + & + & + & - & + \\
\hline HQ588451 & $\delta$-Proteobacteria & + & + & + & - & - \\
\hline HQ588450 & $\gamma$-Proteobacteria & + & + & - & + & - \\
\hline HQ588378 & $\gamma$-Proteobacteria & + & - & - & + & + \\
\hline HQ588544 & $\delta$-Proteobacteria & + & + & - & - & + \\
\hline HQ588424 & JS1 & + & + & - & + & - \\
\hline
\end{tabular}

${ }^{\mathrm{a}}$ Amsterdam = AMSMV Pac and AMSMV Hei of Table 1. ${ }^{\mathrm{b}}$ Kazan $=$ KZNMV Pac and KZNMV Hei of Table 1.

for cold seeps and mud volcanoes (Lösekann et al., 2007; Pachiadaki et al., 2010, 2011), where it was probably outcompeted by the ANMEs. Still within this group, there are branches consisting of phylotypes occurring in cold seeps and carbonates (Teske, 2006).

Finally, two OTUs, HQ588635 and AJ704644 (each of which is present in three of the data sets), were affiliated to the Thaumarchaeota, MG-I, Marine Group-I. This group seems to account for a major portion of all prokaryotic picoplankton in seawater (Karner et al., 2001) and is also found in the marine sedimentary subsurface (Teske, 2006). The OTUs which were retrieved form the studied data bases were also found in a variety of habitats including upwelling systems (EF645847), wetlands (EU420691) and water above seafloor reflecting the cosmopolitan, not methane related distribution of those phylotypes.

\subsection{Bacteria}

The bacterial data sets appear more diverse in terms of species richness since all but one (GoC Nie) contain a high number of OTUs (Table S1). Again the highest absolute number of shared OTUs was observed between AMSMV Pac and KZNMV Pac (Table 2b). The 37 common OTUs constitute 17.4 and $21.0 \%$ of their total bacterial OTUs, respectively. The two different data sets of Amsterdam MV, AMSMV Pac and AMSMV Heij share 22 OTUs corresponding to 10.3 and
$23.9 \%$ of their total bacterial OTUs, respectively. In all other data set comparisons the relative abundance of shared OTUs is $>10 \%$. Strangely, the two different data sets from the Gulf of Cádiz, GoC Nie and GoC Mai, appeared not to have any common OTU, but this might be caused by the fact that the GoC Nie clone libraries were probably not thoroughly sampled.

The most common OTU is the $\delta$-Proteobacteria HQ588562 (Fig. 4, Table 2), which is present in six of the data sets and in all five locations. Interestingly, apart from the five studied locations this phylotype is only found in two other sites, the gas hydrate sediments of Hydrate Ridge, Cascadia Margin (AJ535240) and the marine methane seep of Santa Barbara Basin (AF354160). All these sequences, forming a single OTU, cluster into a distinct clade within the SEEP-SRB1f subgroup of the $\delta$-Proteobacteria (Schreiber et al., 2010). The role of this subgroup in the process of AOM is still unclear.

Another common OTU, HQ588530, belonging to $\delta$ Proteobacteria was found in six of the data sets but only in four of the examined locations (absent from HMMV) has also a limited distribution. Apart from the studied European sites, this phylotype was present in clone libraries from enrichments of Hydrate Ridge sediments, Cascadia Margin (FN549955), as well as clones from direct cell capture of Eel River Basin methane seeps (EU622295). This 
OTU was affiliated in the SEEP-SRB1a subgroup, the members of which are believed to be the syntrophic partners of ANME-2 (a and c subgroups) Archaea (Pernthaler et al., 2008; Schreiber et al., 2010) as well as partners for the ANME-3 (Schreiber et al., 2010). In the same subgroup belongs one more common OTU, HQ588491, present in five of the examined data sets and four locations (not retrieved from KZNMV).

To the SEEP-SRB1e subgroup was affiliated OTU HQ588370, which is shared among four of the data sets and again not present in HMMV. This OTU is more widely spread and is found, apart from enrichments performing AOM, in Hydrate Ridge sediments, Cascadia Margin (AM229187); Gullfaks oil and gas fields sediment, North Sea (FM179902)); Gulf of Mexico cold-seep sediment (AM746087); oil-polluted sediments (JQ580337); subseafloor sediment at the Good Weather Ridge, gas hydrate potential area, SW Taiwan (JQ816985); Arctic marine surface sediment (FN396770); and Sylt sediment, Wadden Sea (AM040136). Although this subgroup of $\delta$-Proteobacteria is associated with the AOM aggregates, the exact ecophysiological role still remains unknown. Three more OTU HQ588451, HQ588544 and HQ588410 (each shared among four data sets) belong to $\delta$-Proteobacteria, pointing out the importance of this group in the AOM hot spots in the European margins.

A member of the candidate division JS1 (HQ588424) and a member of Bacteriodetes (HQ588428) were among the common OTUs. They are both wide spread subsurface groups. Sulfate reducing $\delta$-Proteobacteria, which are very abundant in the studied locations, can utilise a wide spectrum of substrates which are being oxidized completely or incompletely to acetate, supplying their habitat with different forms of organic material as well as reduced sulfur compounds (Webster et al., 2006). Members of JS1 and Bacteriodetes have been associated with acetate incorporation in sulfate reducing environments and that could explain the high abundance of these groups in sediments where AOM driven by sulfate reduction takes place (Pachiadaki et al., 2011).

Data regarding abundance of the JS1 OTU (HQ588424) revealed that it might be a central player in the eastern Mediterranean MVs, especially in Amsterdam MV. This OTU had a persistent appearance in all sediment layers studied with relative abundances that increased from $\sim 2 \%$ at the surface layer to $\sim 34 \%$ at $15 \mathrm{~cm}$ b.s.f. and decreased again to $\sim 12 \%$ at the deepest studied layer, $30 \mathrm{~cm}$ b.s.f.

Two $\gamma$-Proteobacterial OTUs, HQ588450 and HQ588378, seem to be important for the studied system. Each one of them is present in four data sets. Both of them were affiliated to sulfur and sulfide oxidizers or to environmental sequences originating from habitats where sulfur and sulfide oxidation occurred or was predicted. Such microorganisms are energetically fuelled by the sulfide produced by the sulfate reduction of the AOM process, and refuel AOM.
Twenty OTUs were found to be shared among three of the investigated sites. They belong to $\gamma$-Proteobacteria, $\delta$ Proteobacteria, Chloroflexi, $\alpha$-Proteobacteria, Actinobacteria and Acidobacteria. Members of the last four groups are often found in close association with the ANME-SRB consortia (Pernthaler et al., 2008; Zhang et al., 2011) and believed to be using the by-products of AOM. Fifty two OTUs were common between two of the examined data sets. Among the phylotypes that have been found in two or more of the sites investigated here, only three were found to occur exclusively in MV, DQ103602 in Kazan MV (Kormas et al., 2008) and AY592373 in Amsterdam MV (Heijs et al., 2008). To date, no other phylotypes closely related to them have been found.

Community comparisons between analogue/similar habitats are difficult to be made due to different methodological approaches used by each research team, from sampling and nucleic acid extraction to amplification conditions, primers used and analysis of clone libraries. An underestimation of the shared OTUs is assumed, except from studies conducted by the same team and the same protocols. Despite the biases, these comparisons can provide useful information and network analysis of similar environments can unveil the "key players" within complex microbial communities.

It has been stated (Gonzalez et al., 2012, and references there in) that under similar environmental conditions, microbial communities can have strikingly different composition and function; conversely, different community configurations can function similarly. It seems that in some cases, such as the MVs of the European margins, microbial community composition and structure can vary but the major microbiological processes are similar. The presence of few "core" phylotypes in all (or most) of the studied sites implies that these play a central role on the ecosystem functioning.

It is known that AOM, the key process in MVs, is mediated by a consortium of methane oxidizing Archaea and sulfate reducing Bacteria. The importance of this partnership is captured in the created network, since ANME and SRB are the most connected nodes. Other highly-edged notes are the sulfide and sulfur reducers, extremely important for AOM refuelling. Estimation of $\beta$-diversity showed highly dissimilar communities, especially in the case of Bacteria (Pachiadaki et al., 2010) while measurements of geochemical rates (Haese et al., 2003; Niemann et al., 2006b; Omoregie et al., 2008; Maignien et al., 2013) implied different microbial activities (Maignien et al., 2013). However, these different communities occurring in similar, but geographically distant, environments seem to favor the presence of few specific OTUs among many, phylogenetically close, others. Core OTUs are required for the core processes: oxidation of methane, sulfate reduction, and sulfide oxidation. Secondary processes in the same environments, such as the acetate utilization and degradation of complex organic matter, can be probably performed by different OTUs or different groups. Surprisingly, the majority of the core OTUs 
from the European marine MVs seem to be present exclusively in methane-rich marine environments, demonstrating the endemic character of these microorganisms. AOM is a widespread process, that takes place in anaerobic environments worldwide, from rice pads to swamps and marine sediments, but the key OTUs retrieved from the studied databases never clustered with OTUs from terrestrial or fresh-water origin.

This study provides an overview of all the existing data based on cloning/sequencing of 16S rRNA gene data from major mud volcanoes of the eastern Mediterranean Sea, the Gulf of Cádiz and the Norwegian Sea. The sediment prokaryotic communities of these systems, seem to be interconnected through a small number of OTUs. However, these microorganisms are considered of specific ecophysiological role in these sediments, namely methane- and sulfur-mediated mineralization, and are key stone species for methane-dominated habitats. These microorganisms, apart from being the major regulators of methane emission from the oceans at a global scale (Knittel and Boetius, 2009), they are also of interest for deep-sea exploitation of natural resources, like natural gas and hydrocarbons (e. g. Schubotz et al., 2011). Unraveling the diversity, distribution and ecology of such key stone microorganisms is the first step towards a complete comprehension of whole ecosystem functioning setting, thus, the frame for future research in this microbial habitats.

\section{Supplementary material related to this article is available online at: http://www.biogeosciences.net/10/ 2821/2013/bg-10-2821-2013-supplement.zip.}

Acknowledgements. This work was partly supported by the European Commission project HERMIONE (contract no 226354).

Edited by: A. Boetius

\section{References}

Biddle, J. F., Cardman, Z., Mendlovitz, H., Albert, D. B., Lloyd, K. G., Boetius, A., and Teske, A.: Anaerobic oxidation of methane at different temperature regimes in Guaymas Basin hydrothermal sediments, ISME J., 6, 1018-1031, 2011.

Boetius, A., Ravenschlag, K., Schubert, C. J., Rickert, D., Widdel, F., Gleseke, A., Amann, R., Jørgensen, B. B., Witte, U., and Pfannkuche, O.: A marine microbial consortium apparently mediating anaerobic oxidation methane, Nature, 407, 623-626, 2000.

Cita, M. B., Ryan, W. B. F., and Paggi, L.: Prometheus mud-breccia: An example of shale diapirism in the Western Mediterranean Ridge, Ann. Geol. Pays Hellen., 30, 543-570, 1981.

De Beer, D., Sauter, E., Niemann, H., Kaul, N., Foucher, J. P., Witte, U., Schüter, M., and Boetius, A.: In situ fluxes and zonation of microbial activity in surface sediments of the Haakon Mosby Mud Volcano, Limnol. Oceanogr., 51, 1315-1331, 2006.

Dhillon, A., Lever, M., Lloyd, K. G., Albert, D. B., Sogin, M. L., and Teske, A.: Methanogen diversity evidenced by molecular characterization of methyl coenzyme $\mathrm{M}$ reductase A (mcrA) genes in hydrothermal sediments of the Guaymas Basin, Appl. Environ. Microb., 71, 4592-4601, 2005.

Dupré, S., Woodside, J., Foucher, J.-P., de Lange, G., Mascle, J., Boetius, A., Mastalerz, V., Stadnitskaia, A., Ondréas, H., Huguen, C., Harmègnies, F., Gontharet, S., Loncke, L., Deville, E., Niemann, H., Omoregie, E., Olu-Le Roy, K., Fiala-Medioni, A., Dählmann, A., Caprais, J.-C., Prinzhofer, A., Sibuet, M., Pierre, C., and Damstè, J. S.: Seafloor geological studies above active gas chimneys off Egypt (Central Nile Deep Sea Fan), Deep-Sea Res. Pt. I, 54, 1146-1172, 2007.

Gonzalez, A., King, A., Robeson Ii, M. S., Song, S., Shade, A., Metcalf, J. L., and Knight, R.: Characterizing microbial communities through space and time, Curr. Opin. Biotech., 23, 431-436, 2012

Haese, R. R., Meile, C., Van Cappellen, P., and De Lange, G. J.: Carbon geochemistry of cold seeps: Methane fluxes and transformation in sediments from Kazan mud volcano, eastern Mediterranean Sea, Earth Planet. Sc. Lett., 212, 361-375, 2003.

Hanson, C. A., Fuhrman, J. A., Horner-Devine, M. C., and Martiny, J. B. H.: Beyond biogeographic patterns: processes shaping the microbial landscape, Nat. Rev. Microbiol., 10, 497-506, 2012.

Heijs, S. K., Haese, R. R., Van Der Wielen, P. W. J. J., Forney, L. J., and Van Elsas, J. D.: Use of 16S rRNA gene based clone libraries to assess microbial communities potentially involved in anaerobic methane oxidation in a Mediterranean cold seep, Microbial Ecol., 53, 384-398, 2007.

Heijs S. K., Laverman, A. M., Forney, L. J., Hardoim, P. R., and Van Elsas, J. D.: Comparison of deep-sea sediment microbial communities in the Eastern Mediterranean, FEMS Microbiol. Ecol., 64, 362-377, 2008.

Hensen, C., Nuzzo, M., Hornibrook, E., Pinheiro, L. M., Bock, B., Magalhães, V. H., and Brückmann, W.: Sources of mud volcano fluids in the Gulf of Cadiz-indications for hydrothermal imprint, Geochim. Cosmochim. Ac., 71, 1232-1248, 2007.

Karner, M. B., DeLong, E. F., and Karl, D. M.: Archaeal dominance in the mesopelagic zone of the Pacific Ocean, Nature, 409, 507 510, 2001.

Knittel, K. and Boetius, A.: Anaerobic oxidation of methane: Progress with an unknown process, Annu. Rev. Microbiol., 63, 311-334, 2009.

Knittel, K., Lösekann, T., Boetius, A., Kort, R., and Amann, R.: Diversity and distribution of methanotrophic archaea at cold seeps, Appl. Environ. Microb., 71, 467-479, 2005.

Konopka, A.: What is microbial community ecology?, ISME J., 3, 1223-1230, 2009.

Kormas, K. A., Meziti, A., Dählmann, A., De Lange, G. J., and Lykousis, V.: Characterization of methanogenic and prokaryotic assemblages based on mcrA and 16S rRNA gene diversity in sediments of the Kazan mud volcano (Mediterranean Sea), Geobiology, 6, 450-460, 2008.

Larkin, M. A., Blackshields, G., Brown, N. P., Chenna, R., McGettigan, P. A., McWilliam, H., Valentin, F., Wallace, I. M., Wilm, A., Lopez, R., Thompson, J. D., Gibson, T. J., and Higgins, D. G.: Clustal W and Clustal X version 2.0, Bioinformatics, 23, 29472948, doi:10.1093/bioinformatics/btm404, 2007. 
Loncke, L. and Mascle, J.: Mud volcanoes, gas chimneys, pockmarks and mounds in the Nile deep-sea fan (Eastern Mediterranean): Geophysical evidences, Mar. Petrol. Geol., 21, 669-689, 2004.

Lösekann, T., Knittel, K., Nadalig, T., Fuchs, B., Niemann, H., Boetius, A., and Amann, R.: Diversity and abundance of aerobic and anaerobic methane oxidizers at the Haakon Mosby Mud Volcano, Barents Sea, Appl. Environ. Microb., 73, 3348-3362, 2007.

Lykousis, V., Alexandri, S., Woodside, J., Nomikou, P., Perissoratis, C., Sakellariou, D., De Lange, G., Dahlmann, A., Casas, D., Rousakis, G., Ballas, D., and Ioakim, C.: New evidence of extensive active mud volcanism in the Anaximander Mountains (Eastern Mediterranean): The "ATHINA" Mud Volcano, Environ. Geol., 46, 1030-1037, 2004.

Magurran, A. E. and McGill, B. J.: Biological diversity: Frontiers in measurement and assessment, Oxford University Press, Oxford, 368 pp., 2010.

Maignien, L., Parkes, R. J., Cragg, B., Niemann, H., Knittel, K., Coulon, S., Akhmetzhanov, A., and Boon, N.: Anaerobic oxidation of methane in hypersaline cold seep sediments, FEMS Microbiol. Ecol., 83, 214-231, 2013.

Meyerdierks, A., Kube, M., Kostadinov, I., Teeling, H., Glöckner, F. O., Reinhardt, R., and Amann, R.: Metagenome and mRNA expression analyses of anaerobic methanotrophic archaea of the ANME-1 group, Environ. Microbiol., 12, 422-439, 2010.

Mills, H. J., Martinez, R. J., Story, S., and Sobecky, P. A.: Characterization of microbial community structure in Gulf of Mexico gas hydrates: Comparative analysis of DNA- and RNA-derived clone libraries, Appl. Environ. Microb., 71, 3235-3247, 2005.

Niemann, H., Duarte, J., Hensen, C., Omoregie, E., Magalhães, V. H., Elvert, M., Pinheiro, L. M., Kopf, A., and Boetius, A.: Microbial methane turnover at mud volcanoes of the Gulf of Cadiz, Geochim. Cosmochim. Ac., 70, 5336-5355, 2006a.

Niemann, H., Losekann, T., de Beer, D., Elvert, M., Nadalig, T., Knittel, K., Amann, R., Sauter, E. J., Schluter, M., Klages, M., Foucher, J. P., and Boetius, A.: Novel microbial communities of the Haakon Mosby mud volcano and their role as a methane sink, Nature, 443, 854-858, 2006b.

Omoregie, E. O., Mastalerz, V., De Lange, G., Straub, K. L., Kappler, A., Røy, H., Stadnitskaia, A., Foucher, J. P., and Boetius, A.: Biogeochemistry and community composition of iron- and sulfur-precipitating microbial mats at the Chefren mud volcano (Nile deep sea fan, eastern Mediterranean), Appl. Environ. Microb., 74, 3198-3215, 2008.

Orphan, V. J., House, C. H., Hinrichs, K. U., McKeegan, K. D., and DeLong, E. F.: Multiple archaeal groups mediate methane oxidation in anoxic cold seep sediments, P. Natl Acad. Sci. USA, 99, 7663-7668, 2002.

Pachiadaki, M. G., Lykousis, V., Stefanou, E. G., and Kormas, K. A.: Prokaryotic community structure and diversity in the sediments of an active submarine mud volcano (Kazan mud volcano, East Mediterranean Sea), FEMS Microbiol. Ecol., 72, 429-444, 2010.

Pachiadaki, M., Kallionaki, A., Dählmann, A., De Lange, G., and Kormas, K.: Diversity and Spatial Distribution of Prokaryotic Communities Along A Sediment Vertical Profile of A Deep-Sea Mud Volcano, Microbiol. Ecol., 62, 655-666, 2011.
Pernthaler, A., Dekas, A. E., Brown, C. T., Goffredi, S. K., Embaye, T., and Orphan, V. J.: Diverse syntrophic partnerships from deepsea methane vents revealed by direct cell capture and metagenomics, P. Natl Acad. Sci. USA, 105, 7052-7057, 2008.

Pruesse, E., Quast, C., Knittel, K., Fuchs, B. M., Ludwig, W., Peplies, J., and Glöckner, F. O.: SILVA: a comprehensive online resource for quality checked and aligned ribosomal RNA sequence data compatible with ARB, Nucleic Acids Res., 35, 7188-7196, 2007.

Schreiber, L., Holler, T., Knittel, K., Meyerdierks, A., and Amann, R.: Identification of the dominant sulfate-reducing bacterial partner of anaerobic methanotrophs of the ANME-2 clade, Environ. Microbiol., 12, 2327-2340, 2010.

Schubotz, F., Lipp, J. S., Elvert, M., and Hinrichs, K.-U.: Stable carbon isotopic compositions of intact polar lipids reveal complex carbon flow patterns among hydrocarbon degrading microbial communities at the Chapopote asphalt volcano, Geochim. Cosmochim. Ac., 75, 4399-4415, 2011.

Smoot, M. E., Ono, K., Ruscheinski, J., Wang, P.-L., and Ideker, T.: Cytoscape 2.8: new features for data integration and network visualization, Bioinformatics, 27, 431-432, 2011.

Tamura, K., Peterson, D., Peterson, N., Stecher, G., Nei, M., and Kumar, S.: MEGA5: Molecular Evolutionary Genetics Analysis Using Maximum Likelihood, Evolutionary Distance, and Maximum Parsimony Methods, Mol. Biol. Evol., 28, 2731-2739, 2011.

Teske, A. P.: Microbial communities of deep marine subsurface sediments: Molecular and cultivation surveys, Geomicrobiol. J., 23, 357-368, 2006.

Teske, A. and Sørensen, K. B.: Uncultured archaea in deep marine subsurface sediments: Have we caught them all?, ISME J., 2, 318, 2008.

Vanreusel, A., Andersen, A. C., Boetius, A., Connelly, D., Cunha, M. R., Decker, C., Hilario, A., Kormas, K. A., Maignien, L., Olu, K., Pachiadaki, M., Ritt, B., Rodrigues, C., Sarrazin, J., Tyler, P., Van Gaever, S., and Vanneste, H.: Biodiversity of cold seep ecosystems along the European margins, Oceanography, 22, 110-127, 2009.

Vogt, P. R., Cherkashev, A., Ginsburg, G. D., Ivanov, G. I., Crane, K., Lein, A. Y., Sundvor, E., Pimenov, N. V., and Egorov, A. V.: Haakon Mosby mud volcano: a warm methane seep with seafloor hydrates and chemosynthesis-based ecosystem in late Quanternary Slide Valley, Bear Island Fan, Barents Sea passive margin, EOS T. Am. Geophys Un., Supplement, 78, 187-189, 1997.

Webster, G., Watt, L. C., Rinna, J., Fry, J. C., Evershed, R. P., Parkes, R. J., and Weightman, A. J.: A comparison of stableisotope probing of DNA and phospholipid fatty acids to study prokaryotic functional diversity in sulfate-reducing marine sediment enrichment slurries, Environ. Microbiol., 8, 1575-1589, 2006.

Woodside, J. M., Ivanov, M. K., and Limonov, A. F.: Shallow gas and gas hydrates in the Anaximander Mountains region, eastern Mediterranean Sea, Geol. Soc. Sp. Publ., 137, 177-193, 1998.

Zhang, Y., Maignien, L., Zhao, X., Wang, F., and Boon, N.: Enrichment of a microbial community performing anaerobic oxidation of methane in a continuous high-pressure bioreactor, BMC Microbiol., 11, 137, doi:10.1186/1471-2180-11-137, 2011. 
Zinger, L., Amaral-Zettler, L. A., Fuhrman, J. A., Horner-Devine, M. C., Huse, S. M., Welch, D. B. M., Martiny, J. B. H., Sogin, M., Boetius, A., and Ramette, A.: Global patterns of bacterial beta-diversity in seafloor and seawater ecosystems, PLoS ONE, 6, e24570, doi:10.1371/journal.pone.0024570, 2011.
Zitter, T. A. C., Huguen, C., and Woodside, J. M.: Geology of mud volcanoes in the eastern Mediterranean from combined sidescan sonar and submersible surveys, Deep-Sea Res. Pt. I, 52, 457-475, 2005. 